\title{
Best Practice for Incorporating STEM into Rural Schools: Train and Invest in Teacher Leaders (RTP)
}

\section{Ms. Julie Steimle, University of Cincinnati}

Julie Steimle received her Bachelor of Arts in English and Secondary Education from Thomas More College. She served as development director and managed academic programs in two non-profit organizations, Pregnancy Care of Cincinnati and the Literacy Network of Greater Cincinnati, before coming to the University of Cincinnati in 2009. Ms. Steimle initially coordinated UC's Supplemental Educational Services Program. Currently, she is the Project Director of the Cincinnati Engineering Enhanced Math and Science Program.

\section{Dr. Anant R. Kukreti, University of Cincinnati}

ANANT R. KUKRETI, Ph.D., is Director for Engineering Outreach and Professor in the Department of Biomedical, Chemical and Environmental Engineering at the University of Cincinnati (UC), Cincinnati Ohio, USA. He joined UC on 8/15/00 and before that worked 22 years at University of Oklahoma. He teaches structural mechanics, with research in steel structures, seismic analysis and design, and engineering education. He has won five major university teaching awards, two Professorships, two national ASEE teaching awards, and is internationally recognized in his primary research field.

\section{Dr. Catherine Maltbie, University of Cincinnati}

Dr. Cathy Maltbie is a Research Associate at the University of Cincinnati with a joint appointment with the Evaluation Services Center and the Arlitt Child and Family Research and Education Center. She has a BS in Chemical Engineering and a Doctorate in Educational Foundations. Her research areas include evaluation, cognitive and social aspects of educational environments, and STEM education from pre-K through graduate school. 


\title{
Best Practice for Incorporating STEM into Rural Schools: Train and Invest in Teacher Leaders
}

\begin{abstract}
Despite the fact that more than one-fifth of all public school students attend rural schools, these students often lack opportunities enjoyed by their urban and suburban counterparts. Due to their small size and geographic isolation, rural schools often have difficulty attracting talented teachers and tend to offer fewer advanced math and science, AP, and dual credit classes. Likewise, rural public school teachers and students are limited in their access to outside partnerships.
\end{abstract}

This paper outlines a best practice for integrating STEM into rural schools-increasing access to STEM teacher training and support. The University of Cincinnati (UC) extended the opportunity for rural science and math teacher leaders, as well as their urban and suburban counterparts, to participate in the Cincinnati Engineering Enhanced Math and Science (CEEMS) Program (NSF, DRL-1102990) that would provide them with deepened content knowledge, pedagogical training, and long-term coaching on ways to integrate STEM into their coursework. The rural teacher leaders created and implemented contextualized STEM materials that matched rural students' interests and provided training, formally or informally, to their colleagues. In addition, by focusing efforts on teacher leaders rather than students, the program's effects has the potential for sustainability beyond grant funding, as the teacher leaders could influence many students and fellow teachers throughout their careers.

First, the salient details of the courses and professional development program in which teachers participate over two summers are presented. Second, the coaching support to guide the teachers to produce curricular units that are uniquely suited to their classrooms is described. The coaching support continues over the school year as teachers implement the curricular units.

As CEEMS also served urban and suburban districts, the paper will compare baseline data on college and career readiness and evaluation results related to project implementation between the rural schools and all other schools participating in CEEMS. Finally, the paper will explore how participating teacher leaders from rural schools served as proponents of STEM in their buildings in ways that varied from their urban and suburban counterparts and welcomed additional support in their classroom.

\section{Literature review}

Although a number of initiatives have been focused on introducing STEM to under-privileged, urban youth with the hope that this will result in greater college and career readiness, there is evidence to suggest that rural youth may have an even greater need for those opportunities. Byun, Irvin, \& Meece state that, compared to their urban and suburban counterparts, rural youth are less likely to attend selective colleges, more likely to delay post-secondary education, and 
less likely to be continuously enrolled in college. ${ }^{6}$ Part of the discrepancy may be due to rural students' lack of exposure to rigorous coursework. According to Provasnik et al., only 69.2\% of rural public high school students are enrolled in schools offering Advanced Placement (AP) courses, as compared to $95.7 \%$ of students in suburban areas and $93.0 \%$ of students in urban areas. ${ }^{12}$ In addition, a significantly smaller portion of rural high school students take advanced math courses, such as Algebra 2, Trigonometry, Pre-Calculus, and Calculus. ${ }^{6}$

Part of the difficulty may result from math and science teacher recruitment in rural schools. The U.S. Department of Education's Schools and Staffing Survey indicated that rural schools find it difficult to recruit and retain math and science teachers who are certified in their main teaching assignment. ${ }^{13}$ On the positive side, rural teachers tend to stay in the same school longer, an average of 9.0 years, as compared to the national average of 8.4 years for all public school teachers and 7.6 years for urban school teachers. ${ }^{9}$ Thus, if a quality teacher is hired and trained at a rural school, his or her influence may have a longer term impact at that particular school and on its students.

Another dilemma is the geographic isolation of rural schools, which makes it difficult to form partnerships with universities, businesses, non-profits, and other resources that could provide support. These schools have very limited access to educational opportunities provided by science organizations, colleges, and corporations, in comparison to urban and suburban schools. ${ }^{3}$ Furthermore, rural teachers have minimal access to professional development opportunities. ${ }^{4}$ In particular, new teachers in rural schools do not benefit from being paired with mentor teachers who teach the same subject areas, as frequently occurs in urban contexts. ${ }^{5}$

\section{Background}

As a result of these challenges, university partnerships that provide STEM programs and teacher professional development need to find a way to include rural educators, as they are often left out due to their geographic distance. The UC CEEMS program designed a research study on a teacher professional development program that included targeted urban, suburban, and rural schools. The study began in 2012 and is ongoing. Data reported in this paper runs through September 2015.The inclusion of schools from a variety of settings was intentional, as the investigators hoped to gain insight into the effects of the intervention in different locales.

Overall, the grant program provided training and support to participating secondary math and science teachers for two years. In two summers of participation, teachers spent seven weeks taking graduate coursework in science, engineering, and math; participating in professional development workshops modeling engineering design challenge pedagogy; and developing engineering design challenges for their classrooms that address content standards in science or math.

In order for a teacher to apply for the program, he or she had to teach math, science, or a STEM course at the middle school or high school level in one of 14 partner school districts. 
Approximately 20 teachers each year are selected for CEEMS, as teachers receive scholarships and stipends as an incentive for participation and grant funding is limited. The process for selection is competitive as applicants participate in phone interviews, provide letters of reference, and, in some cases, are observed in the classroom. The ideal candidate is organized, has good classroom management skills, incorporates cooperative learning in his/her classroom, and is open to new teaching ideas and constructive criticism. Prior to final selections, applicants attend an orientation meeting where they have an opportunity to learn more about program expectations. At that point, they can decide to "opt out” if the program seems more rigorous than they expected.

The CEEMS Summer Institute for Teachers (SIT) is seven weeks long and each teacher participates for two summers and implements what he/she developed in the summer in the subsequent school years. Teacher participants take 10 graduate credit hours each summer. The coursework models the key pedagogies of the program, challenge-based learning and engineering design. In the courses, teachers participate with their peers in engineering design challenges as they learn new ways to introduce content in science, math, and engineering. When not in classes, teachers participate in professional development workshops that further demonstrate the challenge-based learning and engineering design pedagogies, outline program expectations, and provide other useful tips related to topics such as cooperative learning, use of technology in the classroom, etc.

The end goal of the summer program is for each teacher to fully develop 2-3 curricular units that he/she will implement the following school year. The units will address science and/or math academic standards through the pedagogies of challenge-based learning and engineering design. Examples of units are searchable and archived on the project website. For instance, a chemistry teacher in a rural school introduced his students to the big idea of safe transportation in icy conditions through a few videos. This was a very relevant topic to these students as their rural school frequently had snow days throughout the winter due to impassable roads. Students then brainstormed an essential question related to this big idea: What transportation problems exist in sub-freezing climates? The teacher then challenged the class to work in teams to design a deicing product that includes a blend of chemical compounds and market the product through a commercial. Next, the students brainstormed numerous guiding questions, outlining what content they needed to learn in order to design the deicer as well as questions clarifying the engineering constraints of the project. The teacher had anticipated many of these guiding questions in advance and thus spent time in the summer developing lessons and lab activities that would deliver the content students needed to learn in order to effectively design a deicing product. Student teams all developed unique products; the designs were not "cookie cutter." Some teams wanted to design an environmentally friendly or pet friendly deicer, while other teams were more concerned about affordability or the speed/efficiency at which the product melted the ice. All teams enjoyed using their $21^{\text {st }}$ Century skills to create commercials to market 
their products. The unit addressed the content standards of intermolecular bonding and stoichiometry, in addition to several key science and engineering practices.

The teachers are not alone as they develop and implement the challenge-based learning units. Each teacher is assigned two resource team coaches to assist and provide support. The resource team consists of retired or semi-retired math or science teachers and engineers who mentor the teachers as they develop units in the summer and as they implement those units in the subsequent school years. In addition, teachers in their first year of the program also receive assistance from a doctoral engineering student, called a Fellow, who supports the teacher and students as they implement engineering design in their classrooms. The Fellows recruited for CEEMS take a semester long Instructional Methods course, pedagogy and assessment workshops, and complete a semester-long teaching practicum in an engineering freshman course to prepare for the experience. The resource team and Fellows visit the teachers' classrooms during the school year as units are implemented, thus providing another layer of support for teachers and students. They assist student teams as they work on engineering design challenges, document the unit through photographs and videos, and provide ongoing feedback. Since the start of the project in 2012, teachers have identified the resource team and the Fellows as the most helpful aspect of the program in surveys and focus groups.

Since the grant focuses heavily on approximately 100 teachers in five cohorts from 2012 to 2017, the expectation is that all teacher participants present two professional development workshops or experiences per year to their peers and present at an annual, regional STEM Conference. These presentations help disseminate the project pedagogies, challenge-based learning and engineering design, to other teachers in their school districts, the region, and beyond.

\section{Diversity of partner districts}

Fourteen school districts agreed to participate in CEEMS prior to its funding by advertising the opportunity to its teachers. According to the Ohio Department of Education (2015), the districts were diverse according to typology. ${ }^{11}$ Please see Table $\mathbf{1 .}$

For the purposes of this paper and according to the Ohio Department of Education, the three teachers from Felicity-Franklin Local School District and two teachers from Williamsburg Local School District who participated in CEEMS are considered teachers from rural schools. The data and experiences of these teachers in this paper will be compared to the overall experiences of all teachers in the program. Comparisons will be made at the following levels between rural participants and non-rural participants:

- Ohio Department of Education and the College Board's school level data related to college and career readiness

- Student content knowledge gains as a result of participation: Pre and post-assessment data administered before and after each engineering unit is taught 
- Teachers' change in instructional practices: Based on teacher instructional practices survey, which is administrated at three different points in program.

- Teacher requests for support of doctoral students (Fellows) beyond first year of implementation

- Participating teachers' approaches to fulfilling program-related professional development requirements

The paper will also present anecdotal data from the principals, teachers, and students in the rural schools.

Table 1. Partnering Districts’ Typology

\begin{tabular}{|c|c|c|}
\hline District & $\begin{array}{l}\text { Typology (Ohio Department of } \\
\text { Education, 2015) }\end{array}$ & $\begin{array}{l}\text { \# of program } \\
\text { participants through } \\
\text { September } 2015\end{array}$ \\
\hline Batavia Local Schools & $\begin{array}{l}\text { Small Town-Low Student Poverty \& } \\
\text { Small Student Population }\end{array}$ & 2 \\
\hline $\begin{array}{l}\text { Bethel Tate Local School } \\
\text { District }\end{array}$ & $\begin{array}{l}\text { Rural-High Student Poverty \& Small } \\
\text { Student Population }\end{array}$ & 0 \\
\hline Cincinnati Public Schools & $\begin{array}{l}\text { Urban-Very High Student Poverty \& } \\
\text { Very Large Student Population }\end{array}$ & 25 \\
\hline $\begin{array}{l}\text { Clermont Northeastern } \\
\text { Schools }\end{array}$ & $\begin{array}{l}\text { Small Town-Low Student Poverty \& } \\
\text { Small Student Population }\end{array}$ & 1 \\
\hline $\begin{array}{l}\text { Felicity-Franklin Local School } \\
\text { District }\end{array}$ & $\begin{array}{l}\text { Rural-High Student Poverty \& Small } \\
\text { Student Population }\end{array}$ & 3 \\
\hline Goshen Local Schools & $\begin{array}{l}\text { Small Town-High Student Poverty \& } \\
\text { Average Student Population Size }\end{array}$ & 4 \\
\hline Milford Schools & $\begin{array}{l}\text { Suburban-Low Student Poverty \& } \\
\text { Average Student Population Size }\end{array}$ & 1 \\
\hline New Richmond Schools & $\begin{array}{l}\text { Small Town-Low Student Poverty \& } \\
\text { Small Student Population }\end{array}$ & 0 \\
\hline Norwood City Schools & $\begin{array}{l}\text { Urban-High Student Poverty \& } \\
\text { Average Student Population }\end{array}$ & 5 \\
\hline Oak Hills Local Schools & $\begin{array}{l}\text { Suburban-Low Student Poverty \& } \\
\text { Average Student Population Size }\end{array}$ & 8 \\
\hline Princeton City School District & $\begin{array}{l}\text { Suburban-Low Student Poverty \& } \\
\text { Average Student Population Size }\end{array}$ & 7 \\
\hline West Clermont Local Schools & $\begin{array}{l}\text { Suburban-Low Student Poverty \& } \\
\text { Average Student Population Size }\end{array}$ & 4 \\
\hline $\begin{array}{l}\text { Williamsburg Local School } \\
\text { District }\end{array}$ & $\begin{array}{l}\text { Rural-High Student Poverty \& Small } \\
\text { Student Population }\end{array}$ & 2 \\
\hline Winton Woods City Schools & $\begin{array}{l}\text { Urban-High Student Poverty \& } \\
\text { Average Student Population }\end{array}$ & 4 \\
\hline
\end{tabular}




\section{College and career ready}

The main goal of CEEMS was to train teachers to use engineering as a context to teach math and science academic standards in order to increase student content knowledge and expose middle and high school students to real world applications of the content learned and STEM career possibilities. While not explicitly stated, this goal ties in directly with a state-wide movement to ensure that students are college and career ready. Table 2 lists every high school eligible to participate in CEEMS, along with their district and typology according to the state. The next five columns represent key college and career readiness standards identified by the Ohio Department of Education for the class of 2013: four year graduation rate, percentage of class participating in ACT, ACT mean score, percentage of class receiving a score of 3 or higher on any AP test (STEM or non-STEM course), and percentage of class receiving dual enrollment credits. ${ }^{10}$

The final column identifies which AP courses addressing STEM content, math, science, or computer science, were taught in either the 2013-2014 and/or the 2014-2015 school year, according to the College Board's AP Course Ledger. ${ }^{8}$ Please note that non-STEM related AP courses, such as AP English or AP US History, were not included in this listing. Two school years' worth of data was included as schools with smaller enrollment occasionally offer certain AP courses on alternating years.

When examining Table 2, one notes that 16 of the 30 high schools are part of the same large urban district, Cincinnati Public Schools (CPS). Three of the district's high schools, Walnut Hills, School for Creative \& Performing Arts, and Clark Montessori have competitive admission criteria and therefore boast much higher metrics than the other CPS schools, who report low metrics in almost every category.

The small town schools boasted graduation rates of $90 \%$ or more. However, only a little over half the students in those schools took the ACT. As expected, the suburban schools faired the best in almost all categories.

The schools classified as rural by the Ohio Department of Education are listed in the bottom three rows of the table. ${ }^{11}$ The rural schools have ACT mean scores of 22, 20, and 21 respectively, which aligns closely to the state (21.8) and nationwide composite score average (20.9) for 2013 (ACT, Inc., 2015). However, they offer very few science or math AP offerings compared to the small town or suburban schools in the table with similar metrics.

It appears that potential exists at this school, yet the students are exposed to limited college and career opportunities. For example, at Williamsburg High School, Calculus AB is the only STEM AP course available. The AP Calculus teacher, along with a middle school science teacher, has participated in the program discussed in this paper. In addition to AP Calculus, the same instructor also teaches Chemistry, Physics, and Physical Science. Thus, in this small rural school, all higher level math and science courses are taught by the same individual, as he is the only teacher in the school qualified to teach those courses. 
Table 2. Program Eligible Schools: College and Career Metrics

\begin{tabular}{|c|c|c|c|c|c|c|c|c|}
\hline $\begin{array}{l}\text { High School } \\
\text { eligible } \\
\text { for } \\
\text { program }\end{array}$ & District & Typology & 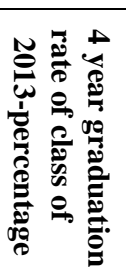 & 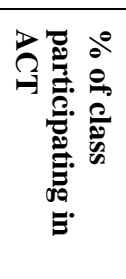 & 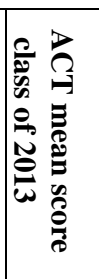 & 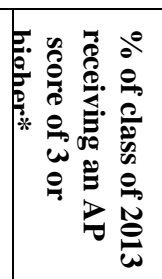 & 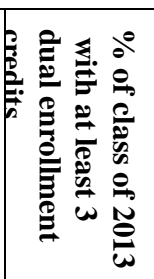 & $\begin{array}{l}\text { STEM AP Authorized Courses in } \\
\text { 2013-2014 and/or 2014-2015 }\end{array}$ \\
\hline Dater & CPS & Urban & $79.1 \%$ & 88.5 & 18 & 10.1 & 0.0 & $\begin{array}{l}\text { Has AP courses, but no STEM AP } \\
\text { courses }\end{array}$ \\
\hline Hughes & CPS & Urban & $70.7 \%$ & 87.0 & 15 & 0.0 & 0.0 & N/A \\
\hline Oyler & CPS & Urban & $40.5 \%$ & 31.0 & 16 & 0.0 & 0.0 & N/A \\
\hline Shroder & CPS & Urban & $81.2 \%$ & 95.7 & 17 & 1.4 & 0.0 & Calculus AB, Calculus BC, Statistics \\
\hline Taft & CPS & Urban & $77.7 \%$ & 65.2 & 14 & 0.0 & 0.0 & Calculus AB \\
\hline Walnut Hills & CPS & Urban & $97.6 \%$ & 100.0 & 26 & 100.0 & .3 & $\begin{array}{l}\text { Biology, Calculus AB, Calculus BC, } \\
\text { Chemistry, Computer Science A, Physics } \\
\text { C: Electricity \& Magnetism, Physics C: } \\
\text { Mechanics, Statistics, Physics B, Physics } \\
\text { 1, Physics 2 }\end{array}$ \\
\hline SCPA & CPS & Urban & $96.6 \%$ & 99.2 & 20 & 29.7 & 1.7 & Biology, Calculus AB, Chemistry \\
\hline Clark & CPS & Urban & $88.0 \%$ & 100.0 & 22 & 28.0 & 0.0 & Calculus AB; Calculus BC \& Statistics \\
\hline $\begin{array}{l}\text { Western } \\
\text { Hills Univ. }\end{array}$ & CPS & Urban & $70.3 \%$ & 71.6 & 16 & 0.0 & 7.7 & N/A \\
\hline $\begin{array}{l}\text { Western } \\
\text { Hills Eng. }\end{array}$ & CPS & Urban & $43.1 \%$ & 60.0 & 15 & 0.0 & 0.0 & N/A \\
\hline Withrow & CPS & Urban & $73.9 \%$ & 23.4 & 15 & 0.0 & 0.0 & N/A \\
\hline Riverview & CPS & Urban & $68.3 \%$ & 65.9 & 17 & 0.0 & 0.0 & N/A \\
\hline Woodward & CPS & Urban & $59.1 \%$ & 45.1 & 15 & 0.0 & 0.0 & N/A \\
\hline Gamble & CPS & Urban & $76.9 \%$ & 76.9 & 17 & 0.0 & 0.0 & N/A \\
\hline Aiken & CPS & Urban & $67.2 \%$ & 65.0 & 16 & 0.0 & 0.0 & N/A \\
\hline Norwood & NCS & Urban & $86.7 \%$ & 60.1 & 21 & 25.9 & 0.0 & Biology, Calculus, Chemistry \\
\hline $\begin{array}{l}\text { Winton } \\
\text { Woods }\end{array}$ & WWCS & Urban & $84.1 \%$ & 56.2 & 19 & 8.7 & 0.4 & $\begin{array}{l}\text { Calculus AB, Calculus BC, Physics B, } \\
\text { Physics } 1\end{array}$ \\
\hline Batavia & BLS & $\begin{array}{l}\text { Small } \\
\text { town }\end{array}$ & $90 / 8 \%$ & 54.9 & 22 & 23.9 & 5.6 & Biology, Calculus AB \\
\hline $\begin{array}{l}\text { Clermont } \\
\mathrm{NE}\end{array}$ & CNE & $\begin{array}{l}\text { Small } \\
\text { town }\end{array}$ & $93.1 \%$ & 59.5 & 21 & 9.2 & 20.6 & $\begin{array}{l}\text { Has AP courses, but no STEM AP } \\
\text { courses }\end{array}$ \\
\hline Goshen & GLS & $\begin{array}{l}\text { Small } \\
\text { town }\end{array}$ & $96.6 \%$ & 56.3 & 20 & 19.3 & 6.8 & Biology and Calculus AB in both years \\
\hline $\begin{array}{l}\text { New } \\
\text { Richmond }\end{array}$ & NREV & $\begin{array}{l}\text { Small } \\
\text { town }\end{array}$ & $90.3 \%$ & 51.1 & 22 & 20.4 & 7.0 & Biology, Calculus AB, Chemistry \\
\hline Milford & MEV & Suburban & $93.6 \%$ & 66.8 & 24 & 78.4 & 1.5 & $\begin{array}{l}\text { Biology, Calculus AB, Chemistry, } \\
\text { Physics C: Electricity and Magnetism, } \\
\text { Physics C: Mechanics (online provider), } \\
\text { Statistics, Calculus BC }\end{array}$ \\
\hline Oak Hills & OHLS & Suburban & $93.5 \%$ & 64.3 & 22 & 70.7 & 2.6 & $\begin{array}{l}\text { Biology, Calculus AB, Calculus BC, } \\
\text { Chemistry, Computer Science A, } \\
\text { Statistics, Physics B, Physics } 1 \text { \& Physics } \\
2\end{array}$ \\
\hline Princeton & PCSD & Suburban & $86.9 \%$ & 60.9 & 19 & 30.7 & .8 & $\begin{array}{l}\text { Calculus AB, Chemistry, Statistics, } \\
\text { Physics B }\end{array}$ \\
\hline Amelia & WCLS & Suburban & $94.6 \%$ & 55.2 & 21 & 20.8 & 15.8 & $\begin{array}{l}\text { Calculus AB, Chemistry, Statistics, } \\
\text { Physics B, Physics } 1\end{array}$ \\
\hline Glen Este & WCLS & Suburban & $90.9 \%$ & 53.1 & 21 & 20.6 & 12.3 & $\begin{array}{l}\text { Biology, Calculus AB, Physics B, } \\
\text { Physics 1, Physics } 2\end{array}$ \\
\hline Bethel Tate & BTLSD & Rural & $97.2 \%$ & 56.3 & 22 & 16 & 10.4 & Calculus AB, Chemistry \\
\hline $\begin{array}{l}\text { Felicity } \\
\text { Franklin }\end{array}$ & FFLSD & Rural & $86.4 \%$ & 44.4 & 20 & 7.4 & 4.9 & Computer Science A (online provider) \\
\hline Williamsburg & WLSD & Rural & $85.9 \%$ & 61.5 & 21 & 3.8 & 24.4 & Calculus AB both years \\
\hline
\end{tabular}


*Not necessarily on a STEM AP course; the percentage of students earning a 3 or higher on an AP test in any subject area

As a result of limited advanced opportunities in rural schools, CEEMS is viewed as a way to challenge students with a new way to learn and introduce them to career possibilities. Yet, with any new program, one must evaluate and see if students grasp needed content as a result of participation. Prior to each program-related unit being implemented in a classroom, teachers administer a pre-assessment based on the academic content standards to be covered in that unit. After unit implementation, the students complete a post-assessment covering the same content standards. Some of the assessments are standard district assessments and others are created by the teachers themselves under the supervision of the resource team coaches. One example of a pre and post assessment for a middle school science unit addressing earth science content, Natural Water Filter, can be found in Appendix A along with student results. In $92 \%$ of program-related units taught through the 2013-2014 school year, students made statistically significant gains from pre to post-assessment. In the classrooms of the five rural teachers, that percentage increased to $100 \%$. However, due to the low number of rural teacher participants, when analyzing non-rural participating teachers' student gains to participating rural teachers' student gains, there was no statistically significant difference, despite slightly higher pre and post-assessment scores in rural classrooms, as shown in Table 3.

Table 3. CEEMS Assessment Data: Rural vs. Non-Rural Classrooms

\begin{tabular}{|c|c|c|c|c|}
\hline $\begin{array}{l}\text { Program Pre and Post Assessment } \\
\text { Data: Rural vs. Non-Rural } \\
\text { Classrooms }\end{array}$ & $\begin{array}{l}\text { Number of } \\
\text { students }\end{array}$ & Mean & Std. Deviation & ANOVA Results \\
\hline \begin{tabular}{|l} 
Rural \\
Average Score (\%) \\
on Pre-Assessment \\
Non-Rural \\
Total
\end{tabular} & 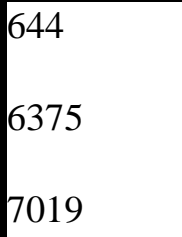 & $\begin{array}{l}43.67 \\
41.24 \\
41.46\end{array}$ & $\begin{array}{l}22.448 \\
24.070 \\
23.934\end{array}$ & $\begin{array}{l}F(1,7017)=6.060 \\
p=0.014^{*}\end{array}$ \\
\hline 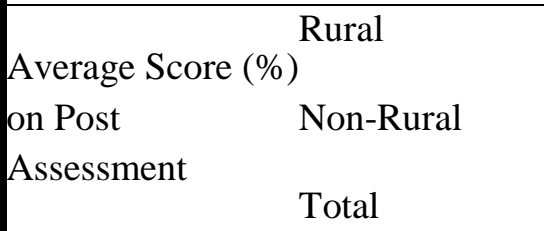 & $\begin{array}{l}645 \\
6414 \\
7059\end{array}$ & $\begin{array}{l}73.49 \\
70.18 \\
70.49\end{array}$ & $\begin{array}{l}18.989 \\
21.473 \\
21.279\end{array}$ & $\begin{array}{l}F(1,7057)=14.193 \\
p<0.001 *\end{array}$ \\
\hline \begin{tabular}{|ll} 
& Rural \\
Percentage Gain & \\
from Pre to Post & Non-Rural \\
& Total
\end{tabular} & $\begin{array}{l}643 \\
6304 \\
6947\end{array}$ & $\begin{array}{l}29.77 \\
29.03 \\
29.10\end{array}$ & $\begin{array}{l}22.456 \\
23.884 \\
23.755\end{array}$ & $\begin{array}{l}F(1,6945)=0.558 \\
p=0.455\end{array}$ \\
\hline
\end{tabular}

*Significant at a 95\% confidence level. 


\section{Instructional practices}

One of the program's aspirations is to change participating teachers' instructional practices. After two years in CEEMS, the hope is that the teachers are utilizing more student-centered pedagogies that challenge students to design solutions to real world problems.

One way to measure changes in teachers' instructional practices is to survey the teachers prior to their involvement in the program, at the program's mid-point, and at the end of the two-year program. The survey examines instructional practices, shown in Table 4, and asks teachers to first self-assess their current usage of these practices using one of four responses: use regularly, use occasionally, have tried it, or never used. Next, the survey asks the teacher to evaluate his or her confidence level regarding the same fifteen practices using one of four responses: very confident, confident, somewhat confident, or not confident.

Within the fifteen instructional practices, three constructs have emerged, which are identified in Table 4. The first construct, "connect," relates math and science content to global or societal issues, real world applications, and STEM careers. The second construct, "guide,” relates to the way in which the teacher facilitates and supports student-centered learning. The final construct, "provide," ties to the integration of the engineering design process into math and science classrooms. Because there are constraints, trade-offs, and performance objectives specified for an engineering design process problem, there will typically be a variety of potential solutions. Thus, the engineering design process is an iterative process that requires the design's revision and optimization. Using knowledge gained (through the guiding questions and activities) and knowledge experiences they bring with them to the class, students identify the best alternative and implement and defend their best unique solution as a culminating activity.

An overall program trend is that teachers report statistically significant increases in their usage and confidence regarding these instructional practices from pre-program to mid-program. Usage and confidence levels tend to remain steady from mid-program to post-program.

It is difficult to tease out differences in current instructional practices survey results between the rural and non-rural teachers since there are only five rural teachers who have participated in the program survey to date. Typically, a minimum number of 30 people per group is recommended for analysis. Keeping in mind that caveat, there are no significant differences at $95 \%$ confidence level in usage of instructional practices when comparing rural and non-rural teachers using ANOVA. However, when examining the rural teachers' confidence in applying the instructional practices, their initial, pre-program confidence levels were significantly lower for the "connect" construct. In other words, prior to beginning CEEMS, the rural teachers seemed less confident about explicitly connecting class content to complex problems or issues with global or societal impact, real world examples and applications, and STEM careers. By the program's mid-point, the rural teachers' confidence level regarding the "connect" construct was parallel to the nonrural teachers, meaning that any gap in confidence levels regarding the "connect” construct that 
existed at the beginning of the program between rural and non-rural teachers was closed by the program's mid-point.

Although the number of rural teachers is small and therefore results should be viewed with caution, it appears that these five teachers were less confident about their ability to connect math and science content with real world problems and STEM careers than other participants prior to beginning the program. By the program’s mid-point, their confidence level had risen significantly and was equivalent to the other participants, even though the non-rural participants were more confident initially.

Table 4: Constructs within Current Instructional Practices Survey

\begin{tabular}{|c|c|c|c|}
\hline Question & Provide & Guide & Connect \\
\hline $\begin{array}{l}\text { 1. Explicitly connect class content to complex problems or issues } \\
\text { with global impact }\end{array}$ & & & $\mathrm{X}$ \\
\hline $\begin{array}{l}\text { 2. Explicitly connect class content to real world examples and } \\
\text { applications }\end{array}$ & & & $\mathrm{X}$ \\
\hline $\begin{array}{l}\text { 3. Explicitly connect these real-world applications to STEM } \\
\text { careers }\end{array}$ & & & $\mathrm{X}$ \\
\hline $\begin{array}{l}\text { 4. Explicitly connect class content to how people in STEM } \\
\text { careers use their knowledge to address societal impacts }\end{array}$ & & & $\mathrm{X}$ \\
\hline $\begin{array}{l}\text { 5. Guide students to break complex global problems in to their } \\
\text { local and more actionable components }\end{array}$ & & $\mathrm{X}$ & \\
\hline 6. Guide students in refining problems & & $\mathrm{X}$ & \\
\hline $\begin{array}{l}\text { 7. Guide students in planning investigations to better understand } \\
\text { different components of problems }\end{array}$ & & $\mathrm{X}$ & \\
\hline $\begin{array}{l}\text { 8. Provide opportunities for students to gather information about } \\
\text { problems or issues of importance }\end{array}$ & $\mathrm{X}$ & & \\
\hline $\begin{array}{l}\text { 9. Provide students with opportunities to explore multiple } \\
\text { solution pathways for problems }\end{array}$ & $\mathrm{X}$ & & \\
\hline $\begin{array}{l}\text { 10. Guide students in weighing the pros and cons of different } \\
\text { solution pathways }\end{array}$ & & $\mathrm{X}$ & \\
\hline $\begin{array}{l}\text { 11. Provide opportunities for students to test their solution } \\
\text { pathways }\end{array}$ & $\mathrm{X}$ & & \\
\hline $\begin{array}{l}\text { 12. Guide students in evaluating the results of their solution } \\
\text { pathways }\end{array}$ & & $\mathrm{X}$ & \\
\hline $\begin{array}{l}\text { 13. Provide students with opportunities to refine and retry a } \\
\text { solution pathway }\end{array}$ & $\mathrm{X}$ & & \\
\hline $\begin{array}{l}\text { 14. Provide opportunities for students to communicate their } \\
\text { solution pathways and results to others }\end{array}$ & $\mathrm{X}$ & & \\
\hline $\begin{array}{l}\text { 15. Provide opportunities for students to take responsibility for the } \\
\text { decisions they made about the processes used in solving } \\
\text { complex problems }\end{array}$ & $\mathrm{X}$ & & \\
\hline
\end{tabular}




\section{Teacher requests for doctoral student support}

Starting in 2013-2014 with Cohort 2, teachers in their first year of CEEMS received additional support from trained doctoral engineering students or Fellows. This was in addition to support received from two resource team members. The Fellows worked directly in the teachers' classrooms, assisting with student groups as they implemented engineering design challenges and helping teachers develop authentic engineering experiences for students. Except for Cohort 1, teachers were guaranteed to have a Fellow assigned to their classrooms during the first year of their classroom implementation. However, there were not enough Fellows available to support all teachers in their second year. In 2015-2016, three of the four Fellows were assigned to first year teachers and the fourth Fellow was available to support second year teachers who voluntarily requested extra help. Of the four second year teachers who requested extra help, three were from rural schools. In addition, the rural teachers requested that the Fellow help in their classrooms at other times besides unit implementation. According to these teachers, it was a rare treat for outside individuals to come and help in their classrooms. The Fellow was more than just an extra hand in the classroom. He or she was also a role model to the students, some of whom had never met an engineer or had very few, if any, members of their family who completed college.

While the statement above may also be true of many students in urban settings, those schools are generally in locations where outside community partnerships and resources were more readily available. In fact, one of the urban schools served by CEEMS, Hughes STEM High school, lists 20 community partners on its website. ${ }^{7}$ As noted by Ahram, Stembridge, Fergus, and Noguerra, this can often lead to fragmentation as too many contradictory initiatives are being implemented at one time. ${ }^{2}$ The three rural districts in the CEEMS partnership list no outside partnerships on their respective websites. While those partnerships may exist in the rural schools, they certainly do not seem exist in abundance as they do with the urban schools with locations more geographically accessible to businesses, universities, and community organizations.

\section{Professional development \& propagation of program pedagogies}

Each teacher participant in the program is required to conduct two professional development workshops or experiences per year in addition to presenting at an annual regional STEM Conference. Each presentation must highlight units developed as part of the program or skills they have learned as part of program participation. The hope is that these professional development opportunities will propagate the program's pedagogies to those not able to commit to an intensive two-year program. Teachers can choose from a number of options to fulfill their professional development requirement:

- Presenting at school staff or department meetings

- Presenting at regional meetings, such as High Schools That Work or Middle Schools That Work 
- Presenting at a regional or national conference

- Leading or co-leading a workshop at the Summer Institute for Teachers

- Mentoring a non-CEEMS participant through the process of developing and implementing an engineering design challenge

While the five rural teachers used all the above mentioned options to fulfill their professional development requirement, they were more likely than teachers in other settings to choose options where they mentored teachers within their own schools or within neighboring schools to employ some of the program's pedagogies and strategies. One rural teacher, CB, made four presentations over two years at High Schools That Work professional development days or professional development days at his school, Williamsburg High School, and a neighboring small town school, Clermont Northeastern High School. His involvement in the program led to interest from a middle school science teacher within his district, who applied to and started the program in 2014. A third teacher from Williamsburg will begin CEEMS in 2016.

In addition, the original teacher participant from Williamsburg, CB, has now been slated to teach an engineering class at his high school in addition to his other upper level science and calculus classes. Due to the district's involvement in this program, there is an emerging interest in engineering among the students, thus prompting the high school to add the class to its offerings. CB seemed to be the likely candidate to teach the course, due to his involvement in CEEMS. He also witnessed the impact of hands-on, engineering design challenges on students. During his second academic year in the program, CB reported students coming up to him and saying, "We want you to teach this way all the time (using engineering design challenges)."

A second rural teacher, MW, completed two of her four professional development requirements by presenting at High Schools That Work and in a department meeting at her school, FelicityFranklin. However, she also chose to provide one-on-one mentoring to a fellow teacher from her school by meeting with her and explaining the pedagogies associated with the program. That same teacher, BF, decided to apply to the program, was accepted, and now serves as an advocate of program pedagogies throughout Felicity-Franklin.

BF made a tremendous impact on one particular science teacher in her rural school through professional development. She mentored "Holly" through the process of creating and implementing two engineering design challenge units and reflected upon the experience:

My first PD (professional development) experience took place in December. I created a unit to team teach with our $8^{\text {th }}$ grade science teacher, Holly. She was very excited about the experience. I shared the lesson plans with her and secured all necessary materials for the unit. I taught the first class and then we team taught the next 2 classes and then she taught the last class on her own. She felt confident by the $4^{\text {th }}$ class.

My second PD experience took place in May. I shared BD (another rural teacher in program)'s MagLev unit with Holly... I told her I would help her in anyway except I 
could not be there to teach the unit... We are planning on meeting this summer to plan a life science unit and maybe more. This is the first time that Holly has ever been excited about teaching science.

In addition, BF spent time with another teacher from her school who applied to and was accepted into the program, MP. She reflected on that experience as well: "I also spent a lot of time with MP. I guided her as much I could with each of her units. I was always there for her when she needed me. I really enjoyed being her mentor. She had some bang up units.

MP, in turn, mentored another teacher at the same small, rural school to help her develop an engineering design challenge for her classroom. Her reflection on the experience follows:

For my second PD, I met with the science fifth grade teacher from my school. I wanted to help her create an engineering design activity for the 2015-2016 school year. We did not have time to create an entire unit but instead used one of her existing activities to incorporate the EDP (engineering design process). During the beginning of the year, her class would use a pre-made template to make a basic loop airplane and measure the distance it traveled. She felt this activity was a great icebreaker while working on team building and measurement skills.

I helped her modify the activity to reflect the engineering design process. Students will use the engineering design process to test one variable on the basic loop airplane. They will observe how changing one variable will impact its distance traveled. Each class will change only one variable: length, number of loops, material of loops, size of loops, size of straw holes, or material of airplane body. They will collect the data and display it graphically. Students will use the data collected to improve the basic loop airplane.

After meeting with the teacher, I could tell she felt more comfortable about implementing the engineering design process. She realized she was doing most of the EDP but never made the students document their work. She feels this layout will help her gauge their understanding while keeping them on task. We are planning on creating another activity together. Our goal is to revamp one of her units to incorporate the EDP.

This one rural middle school, Felicity-Franklin Middle School, with an enrollment of 287 students in four grades in 2013-2014, ${ }^{10}$ has now had three teachers participate in the program. Only 11 teachers in the building would qualify for the program, including the math and science teachers, the STEM gifted teacher, and the math and science enrichment teachers. These three teachers serve as mentors to their peers who cannot formally participate in the program due to other commitments. The impact of the program on this small school has not gone unnoticed. The middle principal stated in an email to the CEEMS Program Director:

I would have to say that this is one of the best programs that I have seen. The amount of professional development, mentorship and support that is given in my opinion is 
outstanding! It is very difficult to get that kind of support in small rural districts like ours. To have an engineer come to our school to help our teachers and work with our students has been tremendous. I know that the teachers also feel that this is one of the best things they have done in their teaching career.

Even the superintendent has bought into the pedagogies. He wants the entire middle school and high school to adopt and employ the program's pedagogies. In fact, an entire half day of mandatory district professional development was devoted to this topic with two of the teachers who were current or past participants serving as presenters, as explained by the resource team member assigned to Felicity-Franklin in an email to the Program Director:

In the summer I told you that the Felicity-Franklin Superintendent would like all of the MS and HS teachers to start doing "CEEMS type" units. Tuesday is a PD day and it will be used to start the process of learning what a "CEEMS unit" looks like. MP, BF, and I are going to co-present in the morning. This will be an interactive session. MP is going to demonstrate how to initiate the Challenge, big idea, questions, $B F$ is going to do the EDP (engineering design process) and I am going to focus upon team work and how to get started.

In both the rural districts where teachers have participated in the program, there seems to be changes that will result in sustainability after grant funds expire. In Williamsburg, the high school initiated an engineering class in response to student interest generated from teachers in the program changing the way they taught academic content. In Felicity Franklin Local School District, the Superintendent noticed the energy, excitement, and academic impact of the program and exhorted all district secondary teachers adopt the same strategies. He indicated this shift as a priority by allocating a half day of mandatory professional development to the training.

In contrast, teacher participants from urban, suburban, and small town schools rarely mentor other teachers in their schools regarding CEEMS pedagogies in the intensive way described by the rural teachers. At most, they would share their program-related units of instruction at staff or department meetings to fulfill professional development requirements.

\section{Conclusions}

Due to the small number of rural participants in the program, it is difficult to make a quantitative argument that the program's impact is greater in rural schools, as opposed to the urban, suburban, and small town participating in the program. However, perhaps due to the lack of other community support and programs in rural schools, the rural teachers anecdotally report a greater impact on their teacher practices that extend to their students and other non-program participating teachers within their schools. Outside support from the Fellows is requested, even when rural teachers are not working on program-related units of instruction and even after teachers' first year in the program when Fellows' support is optional. Mentoring other teachers in the school, beyond sharing about the program in staff or department meetings, is much more 
common. School culture also seems to be impacted in the two rural schools participating, as one school implemented an engineering program as a direct result of teacher participation and the superintendent of the other rural district directed all his secondary teachers to adopt program pedagogies. In none of the other partner school districts did a superintendent take such a strong stance in favor of the program's pedagogies. While more study with larger numbers of rural teachers is necessary to draw conclusions, perhaps more outside programs interested in instituting systemic change should considering focusing on rural schools, as opposed to directing most of their efforts to geographically closer urban schools.

\section{Bibliography}

1. ACT, Inc. (2015). 2013 ACT national and state scores. Retrieved December 2015, 2015, from http://www.act.org/newsroom/data/2013/states.html

2. Ahram, R., Stembridge, A., Fergus, E. \& Noguera, P. (2013). Framing urban school challenges: The problems to examine when implementing response to intervention. Retrieved January 6, 2016, from http://www.rtinetwork.org/learn/diversity/urban-school-challenges

3. Avery, L. M. (2013). Rural science education: Valuing local knowledge. Theory into Practice, 52(1), 2835.

4. Barley, Z. A., \& Beesley, A. D. (2007). Rural school success: What can we learn? Journal of Research in Rural Education, 22(1), 1-16.

5. Beesley, A. (2011). Keeping rural schools up to full speed. T H E Journal, 38(9), 26-27.

6. Byun, S., Irvin, M. J., \& Meese, J. L. (2015). Rural-nonrural differences in college attendance patterns. Peabody Journal of Education, 90(2), 263-279.

7. Cincinnati Public Schools. (2015). Hughes STEM partners. Retrieved December 15, 2015, from http://hughesstem.cps-k12.org/about/partners

8. College Board. (2015). AP course ledger. Retrieved December 15, 2015, from https://apcourseaudit.epiconline.org/ledger/

9. Coopersmith, J. (2009). Characteristics of public, private, and bureau of indian education elementary and secondary school teachers in the united states: Results from the 2007-08 schools and staffing survey (First Look, NCES 2009-324 ed.) National Center for Education Statistics.

10. Ohio Department of Education. (2014). Ohio school report cards. Retrieved December 15, 2015, from http://reportcard.education.ohio.gov

11. Ohio Department of Education. (2015). Typology of ohio school districts. Retrieved January 5, 2016, from http://education.ohio.gov/Topics/Data/Accountability-Resources/Ohio-Report-Cards/Typology-of-OhioSchool-Districts

12. Provasnik, S., Kewal Ramani, A., Coleman, M. M., Gilbertson, L., Herring, W., \& Xie, Q. (2007). Status of education in rural America. National Center for Education Statistics, NCES 2007-040

13. US Department of Education. (2007-08). In National Center for Education Statistics (Ed.), Schools and staffing survey (SASS). Washington D.C. 


\section{Appendix A. Example of One Unit Pre/Post Assessment \& Results: Natural Water Filter}

\section{Pre-Assessment for Unit: Natural Water Filter}

1) The rate at which water can pass through a substance is called
a) Flow
b) Fast
c) Permeability
d) Slow

2) Which of the following has the greatest effect on the ability of soil to hold water?
a) The age of the soil particles
b) The size of the soil particles
c) The color of the soil particles
d) The luster of the soil particles

3) What do scientists use to classify the different types of soil?
a) Climate
b) Plant types
c) Soil composition
d) Size of animal population

4) Soils in some regions of Ohio have a high sand content. Which of the following properties of sandy soil might affect its use in agriculture?
a) Sand is porous. Water quickly goes through sand carrying nutrients with it.
b) Because sand is composed mostly of clay, it is too hard for the roots to grow.
c) Sand is very absorbent. It holds too much water and can drown the plants.
d) Sand contains chemicals such as silicon dioxide which are harmful to most plants.

5) Which statement about soil particle size form largest to smallest is correct?
a) Sand, gravel, clay, silt
b) Gravel, sand, silt, clay
c) Gravel, silt, sand, clay
d) Gravel, sand, clay, silt

During a heavy rainstorm, soil samples A and B both became saturated with water. However, 10 minutes after the storm ended, the soils appeared as shown.

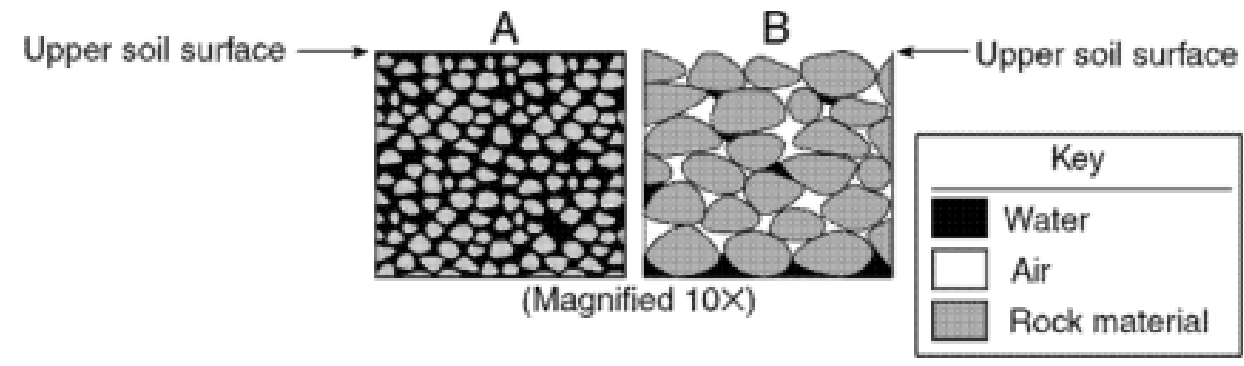


6) Which statement best explains the observed change in the water content of the soil samples?
a) The permeability of $B$ is greater than the permeability of $A$.
b) The porosity of $B$ is greater than the porosity of $A$.
c) The surface runoff of $B$ is greater than the surface runoff at $A$.
d) The permeability of $A$ is greater than the permeability of $B$.

7) Through which of the following loose soil materials does water infiltrate fastest?
a) clay
b) silt
c) sand
d) pebbles

8) Using the Soil Composition Triangle below, identify which soil type has a balanced property mix of the three key components.
a) Loam
b) Silt loam
c) Silty clay
d) Clay loam

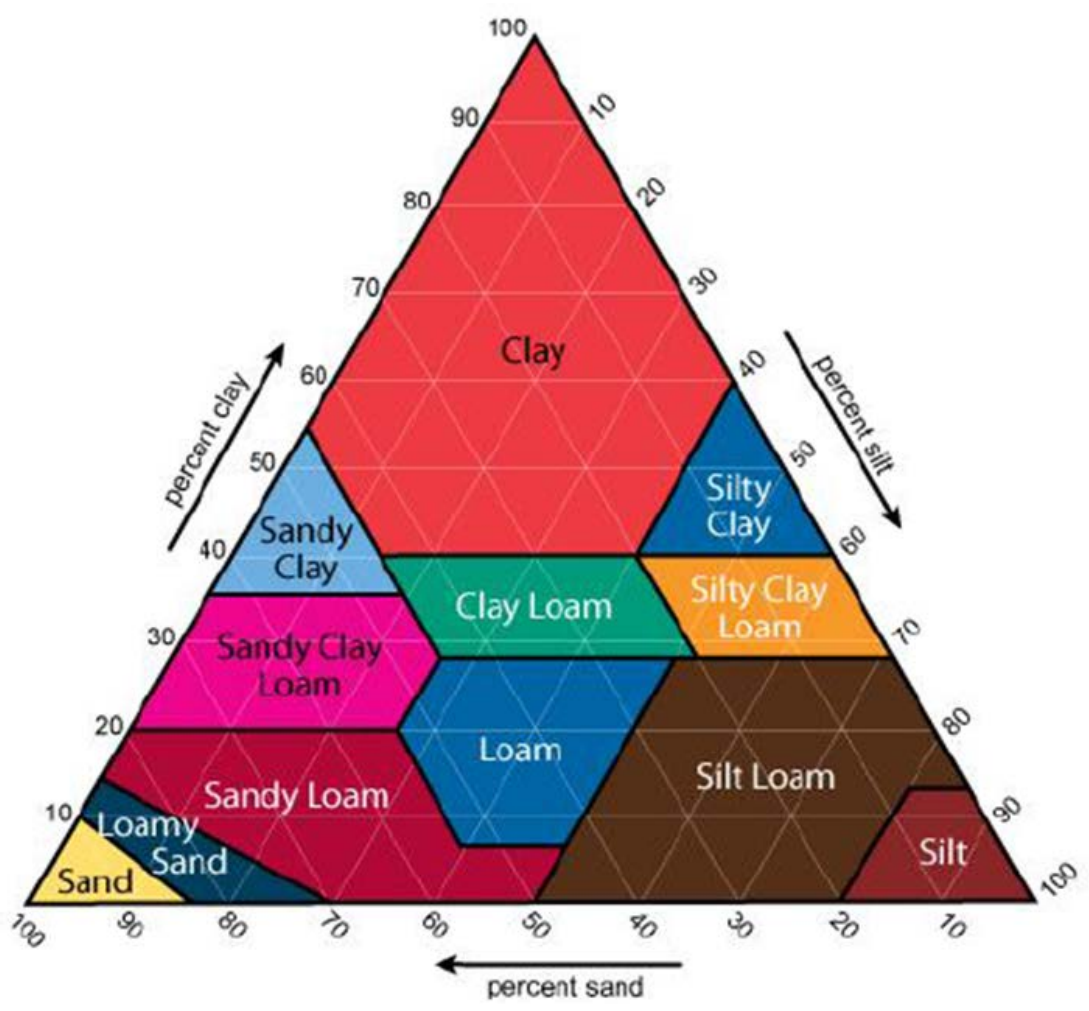

9) Soil samples A through D below have the same volume packing, but contain different percentages of various particle sizes.

Sample A: $75 \%$ clay and $25 \%$ silt

Sample B: $50 \%$ clay and $50 \%$ sand 
Sample C: $25 \%$ clay and $75 \%$ sand

Sample D: $25 \%$ sand and $75 \%$ silt

Which sample most likely has the greatest permeability?
a) $A$
b) $B$
c) $\mathrm{C}$
d) $D$

10) The diagrams below represent four permeable sediment samples. The sediments are composed of the same material, but differ in particle size and sorting. Which sediment sample will most likely have the fastest groundwater infiltration rate?

a)

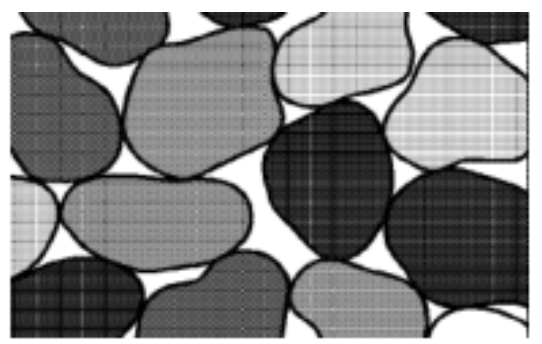

c)

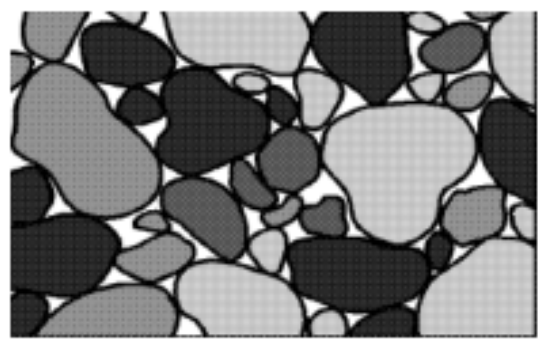

b)

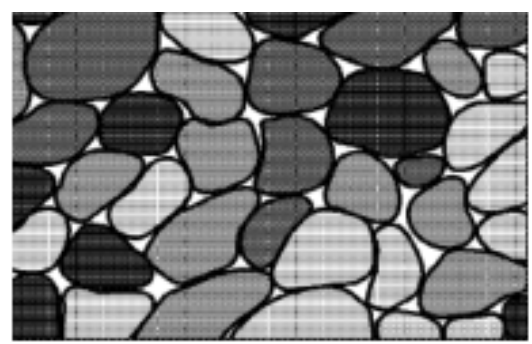

d)

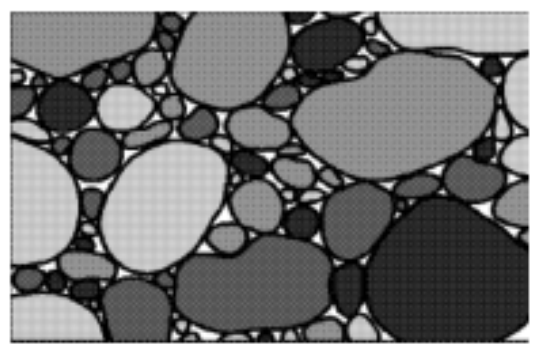

11) Which graph best represents the general relations between soil particle size and the permeability rate of infiltrating rainwater?
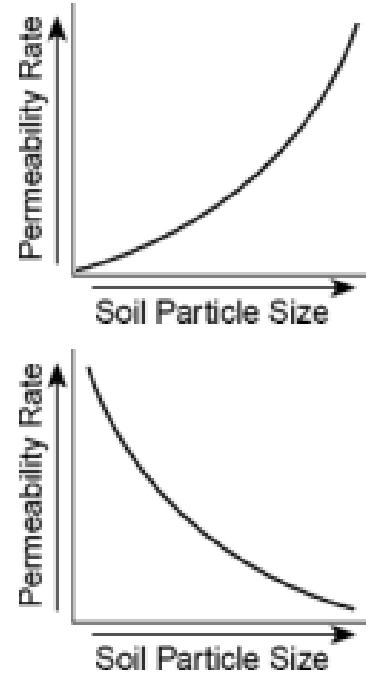

b)

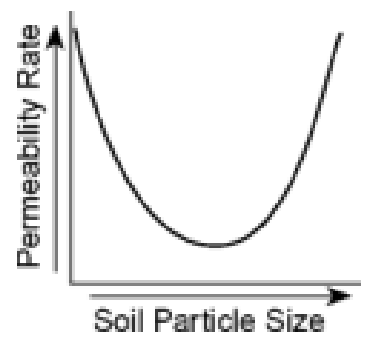

d)

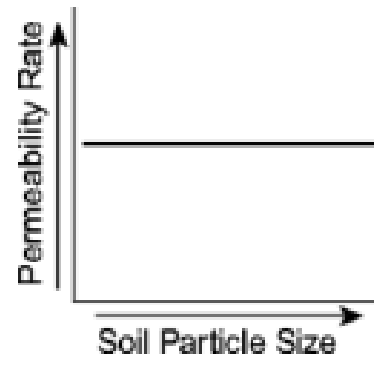




\section{Post-Assessment for Unit: Natural Water Filter}

1) The rate at which water can pass through a substance is called
a) Flow
b) Fast
c) Permeability
d) Slow

2) Which of the following has the greatest effect on the ability of soil to hold water?
a) The age of the soil particles
b) The size of the soil particles
c) The color of the soil particles
d) The luster of the soil particles

3) What do scientists use to classify the different types of soil?
a) Climate
b) Plant types
c) Soil composition
d) Size of animal population

4) Soils in some regions of Ohio have a high sand content. Which of the following properties of sandy soil might affect its use in agriculture?
a) Sand is porous. Water quickly goes through sand carrying nutrients with it.
b) Because sand is composed mostly of clay, it is too hard for the roots to grow.
c) Sand is very absorbent. It holds too much water and can drown the plants.
d) Sand contains chemicals such as silicon dioxide which are harmful to most plants.

5) Which statement about soil particle size form largest to smallest is correct?
a) Sand, gravel, clay, silt
b) Gravel, sand, silt, clay
c) Gravel, silt, sand, clay
d) Gravel, sand, clay, silt

6) During a heavy rainstorm, soil samples $A$ and $B$ both became saturated with water. However, 10 minutes after the storm ended, the soils appeared as shown.

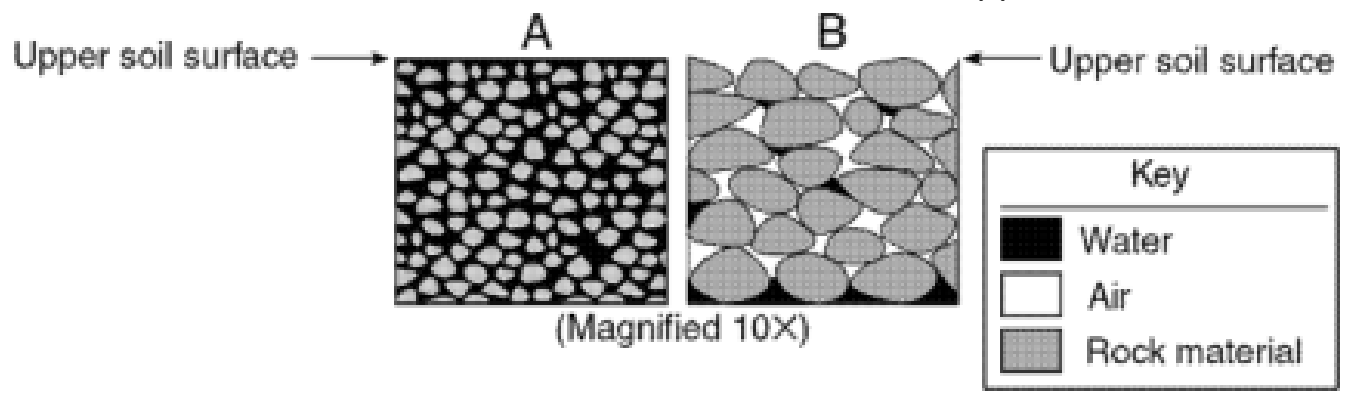

Which statement best explains the observed change in the water content of the soil samples?

a) The permeability of $B$ is greater than the permeability of $A$. 
b) The porosity of $B$ is greater than the porosity of $A$.

c) The surface runoff of $B$ is greater than the surface runoff at $A$.

d) The permeability of $A$ is greater than the permeability of $B$.

7) Through which of the following loose soil materials does water infiltrate fastest?
a. clay
b. silt
c. sand
d. pebbles

8) Using the Soil Composition Triangle below, identify which soil type has a balanced property mix of the three key components.
a) Loam
b) Silt loam
c) Silty clay
d) Clay loam

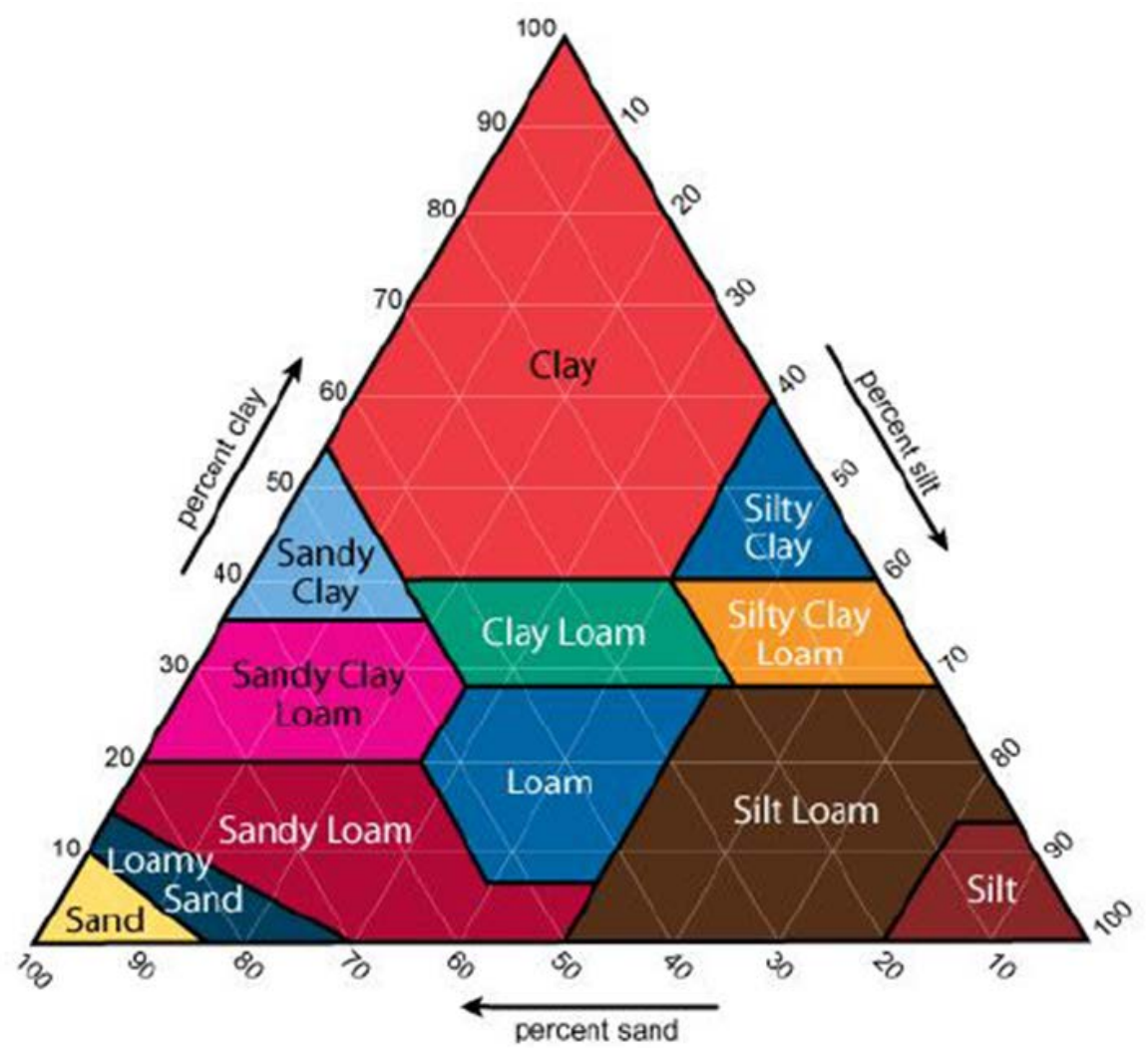

9) Soil samples $A$ through $D$ below have the same volume packing, but contain different percentages of various particle sizes.

Sample A: $75 \%$ clay and $25 \%$ silt

Sample B: $50 \%$ clay and $50 \%$ sand

Sample C: $25 \%$ clay and $75 \%$ sand

Sample D: $25 \%$ sand and $75 \%$ silt 
Which sample most likely has the greatest permeability?
a) $\mathrm{A}$
b) $B$
c) $\mathrm{C}$
d) $D$

10) The diagrams below represent four permeable sediment samples. The sediments are composed of the same material, but differ in particle size and sorting. Which sediment sample will most likely have the fastest groundwater infiltration rate?

a)

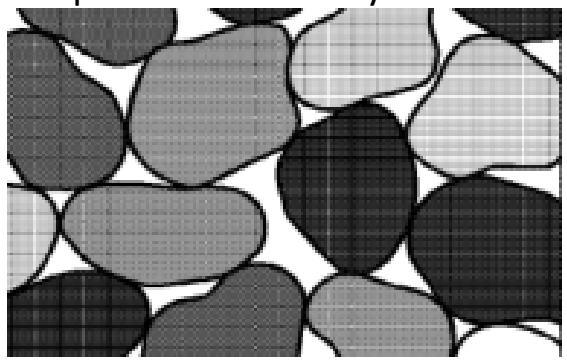

c)

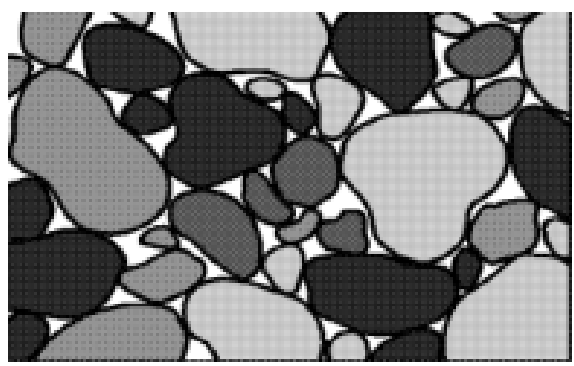

b)

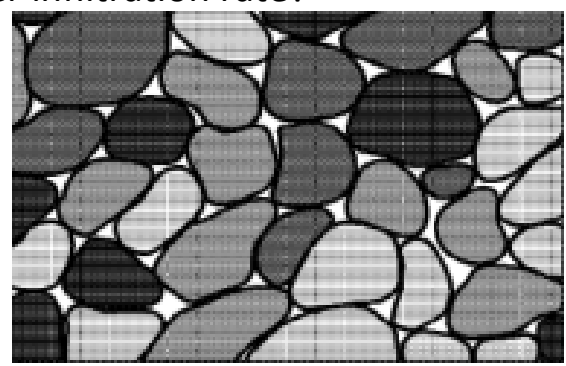

d)

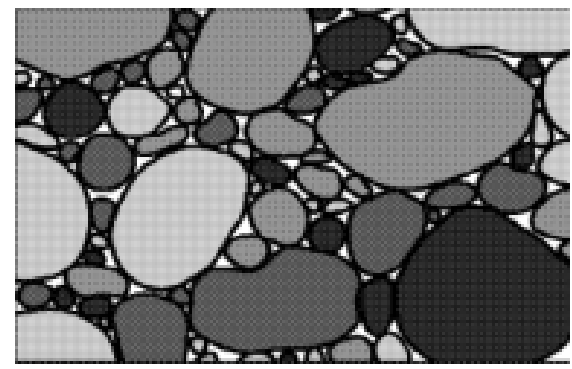

11) Which graph best represents the general relations between soil particle size and the permeability rate of infiltrating rainwater?
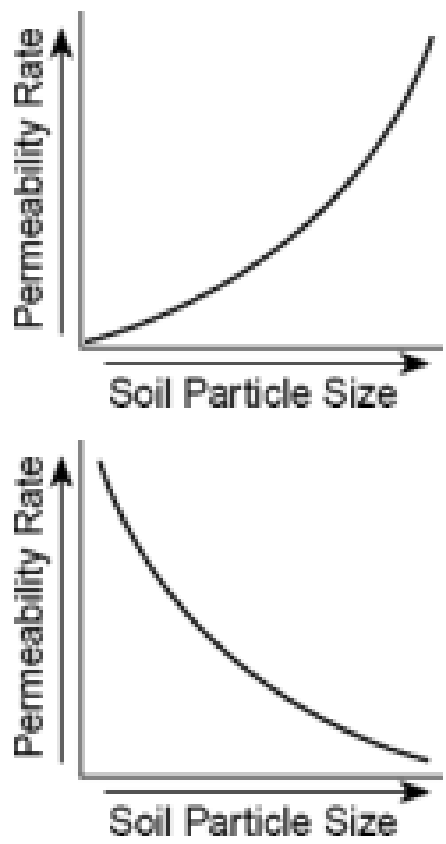

b)

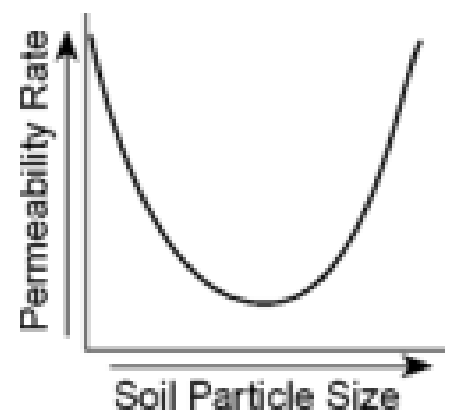

d)

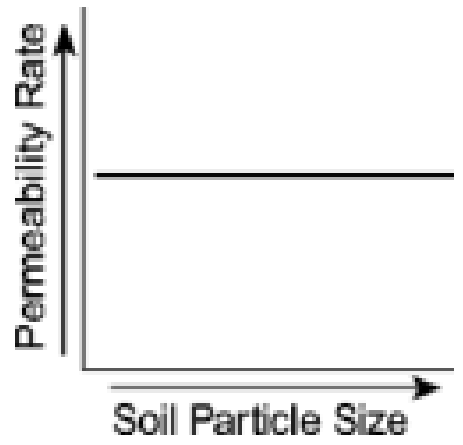




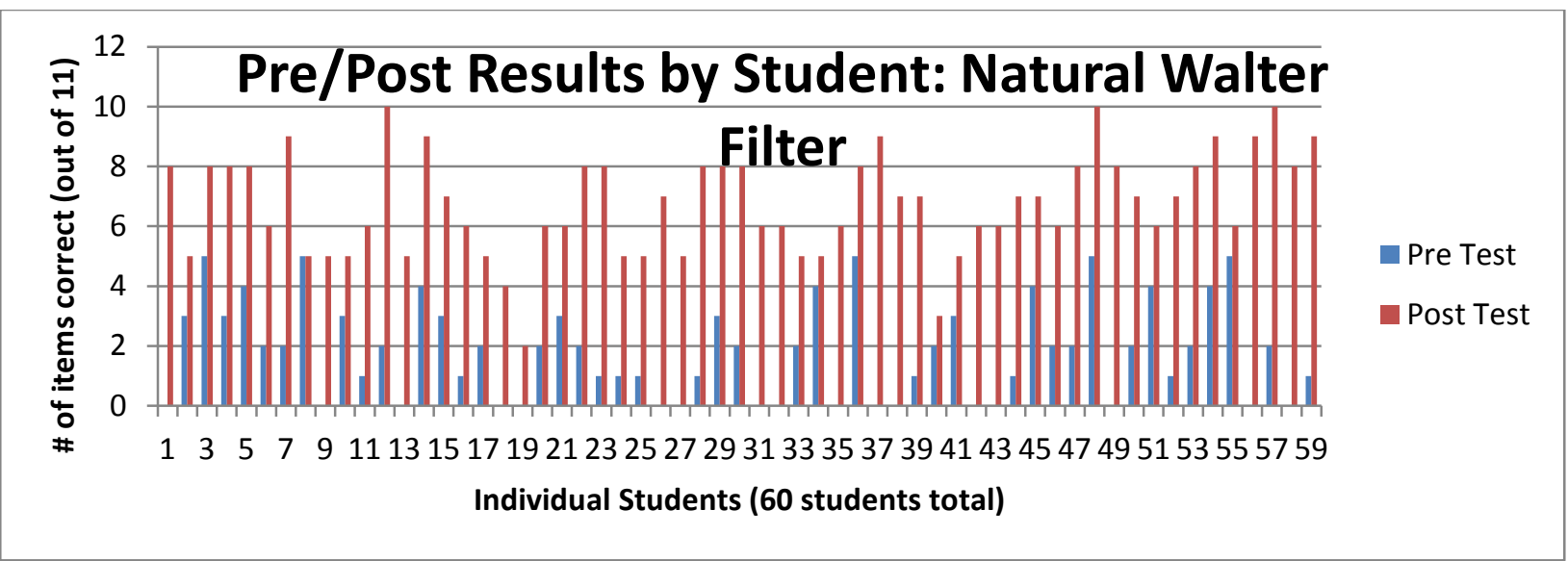

Both the pre-assessment and the post-assessment contained 11 items. Out of 60 students, one did not complete the post-assessment. Of the others, the average pre-test score was 1.8 and the average post-test score was 6.8. The percentage gain was $279.14 \%$. 